\title{
URBAN SETTLEMENT IN THE KYIV REGION: DYNAMICS AND STRUCTURE
}

\author{
Anatoly DOTSENKO
}

\author{
Open International University of Human Development "Ukraine", Kyiv, Ukraine
}

\begin{abstract}
The article deals with the socio-geographical processes of the development of urban settlement in a specific region of Ukraine, such as Kyiv Region, where a relatively large, branched and stable urban settlement network has historically been formed. In the process of functioning of this network, certain features and disproportions of the structure of the urban network, in particular towns and cities of urban type, have been identified, which has caused some problems for the further development of urban settlements. Geographical situation (location around the Ukrainian capital) makes significant influence on the development of urban settlements in the Kyiv region. Over the past 27 years there have been significant shifts due to its dynamism: e.g., two new cities emerged on the basis of urban-type settlements; one city has moved from the middle-size to the small category; two large villages have been moved to the category of urban-type settlements, etc. Multivectoral socio-economic development resulted in significant differences in the urban settlement systems of the Kyiv region and adjacent regions. Taking into account the tendency of urban settlement system development in 2001-2016, as well as peculiarities of the structure of urban and urban-type settlements, the author developed the forecast of the development of urban settlements in the Kyiv region and justified directions for solving their problems. Solving the problems of socio-economic development of urban settlements in the Kyiv region requires a differentiated approach to the study of settlements, depending on their population, functions, geographical location, etc. The problem of activating the socio-economic development of small cities is particularly acute. This problem at the beginning of the XXI century began to be gradually solved in the process of implementing two national programs for small cities, but these programs have not been implemented due to the termination of the state funding. Monofunctional small towns of Kyiv region need special attention. The main directions of their development are: technical and managerial improvement of existing enterprises, construction of new industrial enterprises, operationally interconnected with the existing ones, increase of investments, strengthening of transport and social infrastructure, thus contributing to attractiveness and competitiveness of these cities.
\end{abstract}

Key words: region, settlement, city, system, structure, territory.

DOI: https://doi.org/10.17721/2413-7154/2018.80.33-39

UDC: 911.375

Received: February 25, 2018.

Revised: March 06, 2018.

Accepted: December 28, 2018.

\section{МІСЬКЕ РОЗСЕЛЕННЯ У КИЇВСЬКІЙ ОБЛАСТІ: ДИНАМІКА ТА СТРУКТУРА}

\section{Анатолій ДОЦЕНКО}

\author{
Відкритий міжнародний університет розвитку людини «Україна», Київ, Україна
}

Анотація: У статті розглянуті суспільно-географічні процеси розвитку міського розселення у такому специфічному регіоні України, як Київщина, де історично сформувалася відносно густа розгалужена та стабільна міська поселенська мережа. В процесі функціонування цієї мережі виявилися певні особливості та диспропорції структури міської мережі, зокрема міст та селищ міського типу, що зумовило деякі проблеми подальшого розвитку міського розселення. Значний вплив на розвиток міського розселення у Київській області мало географічне положення її навколо столиці м. Києва. За останні 27 років відбулися помітні зрушення через її динамічність: виникло два нових міста на базі селищ міського типу; одне місто перейшло з категорії середніх до категорії малих; два великих села переведені до категорії селищ міського типу тощо. Істотні відмінності систем міського розселення Київської області та суміжних регіонів $\epsilon$ результатом їх різновекторного соціально-економічного розвитку. Враховуючи тенденцію розвитку міського розселення у 2001-2016 рр., особливості структури міст і селищ міського типу, у статті було розроблено прогноз розвитку міського розселення у Київській області та обгрунтовані напрями вирішення їх проблем. Вирішення проблем соціально-економічного розвитку міських поселень Київської області потребує диференційованого підходу до вивчення поселень в залежності від їх людності, функцій, географічного положення тощо. Особливо гостро стоїть проблема активізації соціально-економічного розвитку малих міст. Ця проблема на початку XXI ст. почала повільно вирішуватися в процесі реалізації двох загальнодержавних програм по малих містах, але через припинення їх державного фінансування ці програми так і не були виконані. Окремої уваги потребують 14 монофункціональних малих міст Київщини. Основними напрямами розвитку другого типу малих міст має бути підвищення технічного рівня і модернізація діючих підприємств, підвищення їх ефективності і конкурентоспроможності, будівництвоновихпромисловихпідприємств, технічновзаємопов'язанихіз діючими, підвищення інвестиційної привабливості цих міст, зміцнення транспортної та соціальної інфраструктури.

Ключові слова: регіон, розселення, місто, система, структура, територія. 
Вступ. Постановка проблеми. Подальший розвиток регіонів України гальмується існуванням низки соціально-економічних та суспільногеографічних проблем, які на жаль в силу різних причин не вирішуються. До останніх належать як загальні проблеми розселення, так i специфічні проблеми міського та сільського розселення. За своєю сутністю розселення є географічним процесом. Тому лише застосовуючи регіональний підхід можна виявити проблеми розвитку міського й сільського розселення та обгрунтувати шляхи їх вирішення. Міське розселення принципово відрізняється від сільського і потребує окремого розгляду та аналізу в кожному регіоні.

Аналіз останніх досліджень та публікацій. Міське розселення у Київській області досліджувалося лише в деяких напрямах. T. В. Буличева розглядала міське розселення як основу формування Київської регіональної системи розселення у складі Київської, Житомирської та Чернігівської областей [1]. Л. М. Воловик вивчала периферійні райони Київської області в яких виявила соціально-економічні проблеми, у тому числі проблеми розвитку малих міст та окреслила напрями їх вирішення [2]. В центрі уваги C.I. Іщука та О.В. Гладкого були економічні проблеми формування та розвитку Київської господарської агломерації, в процесі дослідження якої розроблено функціональну класифікацію міст та визначено вплив міського розселення на формування промислової агломерації [6]. Причому досліджувалися лише міста, що увійшли до агломерації, розташованої на території 10 із 25 районів області. Здійснене Ю.І. Сологубом суспільно-географічне дослідження міського розселення Столичного регіону включало Київську, Житомирську та Чернігівську області. По Київщині він розробив функціональну класифікацію міст та групування районів за рівнем розвитку міського розселення [7].

У 2007 р., досліджуючи міське розселення у Київській області, ми разом 3 О. Т. Великохатько виявили особливості динаміки та структури його у 1990-2005 рр., провели аналіз розвитку міст і селищ міського типу, розробили типологію міст за динамікою людності у 1996-2005 pp. [4]. Значну увагу ми приділяли дослідженню територіальної організації розселення у Київському регіону, в якій головну роль відіграє міське розселення $[3,5]$.

Мета статті полягає у суспільно-географічному дослідженні міського розселення у Київській області, виявленні тенденцій його розвитку та структурних зрушень, а також виявленні актуальних проблем міського розселення та науковому обгрунтуванні шляхів їх вирішення.

Виклад основного матеріалу. У XX ст. значний вплив на розвиток міського розселення у Київській області мало географічне положення їі навколо столиці м. Києва. Історично на території Київщини сформувалася досить густа, розгалужена та відносно стабільна міська поселенська мережа. Так, якщо за переписом населення 1989 р. в області було 55 міських поселень, то на кінець 2016 - 56.
У 2016 р. густота міської поселенської мережі Київської області була більшою порівняно із сусідніми поліськими областями (близько 2-х поселень у розрахунку на 1 тис. км² території проти 1,8 у Житомирській та 1,4 - у Чернігівській).

Важливо зазначити, що за рівнем урбанізації ці поліські області майже однакові. Так, питома вага міського населення до всього населення у 2016 . становила у Київській області 53,5\%, Чернігівській - 53,2\% та Житомирській 53,0\%. Проте ці області помітно відрізняються за структурою міського розселення. У 2016 р. середня людність одного міського поселення була у Київській області 18,6 тис. осіб, Чернігівській - 16,8 тис. осіб і Житомирській 14,9 тис. осіб.

Ці істотні відмінності $є$ результатом різного соціально-економічного розвитку досліджуваних областей, в яких сформувалися різні промисловотериторіальні комплекси. Київський комплекс функціонально пов'язаний із промисловістю м. Києва і за рівнем розвитку вище Житомирського та Чернігівського.

Все це мало значний вплив на структуру міського розселення у Київській області, що відображають статистичні дані таблиці 1.

Як видно з табл. 1, протягом 1989-2016 рр. міська поселенська мережа Київщини збільшилася лише на одне поселення. Проте це не означає їі незмінність, більш того за останні 27 років відбулися помітні зрушення через ii динамічність. За цей період на базі селищ міського типу виникло два нових міста Ржищів (1995) та Буча (2007). Більш динамічною була міська селищна мережа, яка зменшилася на п'ять одиниць. Окрім селищ, переведених до категорії міст, Пуща-Водиця включена до Києва, всі мешканці селищ Поліського та Вільчі Поліського району, розташованих у зоні високого радіаційного забруднення внаслідок Чорнобильської катастрофи, були внесені, а селища зняті з державного обліку.

Протягом досліджуваного періоду відбувався й процес виникнення нових міських селищ. У 2000-2006 pр. два великих села Велика Димерка Броварського району та Калинівка Васильківського переведені до категорії селищ міського типу. У зв'язку із переведенням центру Поліського району у село Красятичі йому було надано статус селища міського типу. Це найменше за людністю міське селище в Київщині (645 осіб).

Дані табл. 1 показують, що в структурі міських поселень переважну більшість складають поселення людністю 5-20 тис. осіб (55,3\%). Проте за кількістю міського населення питома вага цієї групи значно нижча (32\%). Це зумовлено тим, що до цієї групи входять переважно малі міста та середні за людністю міські селища. Незважаючи на це, через багаточисельність даної групи їй слід приділити значну увагу. Більш того розвиток поселень цієї групи гальмує низка проблем, вирішення яких потребує диференційованого підходу до вивчення поселень в залежності

(C) Anatoly Dotsenko 


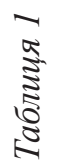

\begin{tabular}{|c|c|c|c|c|c|c|c|c|c|c|c|c|c|c|}
\hline \multirow{6}{*}{ 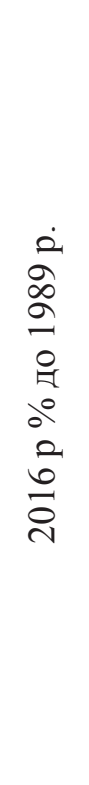 } & \multirow{3}{*}{ 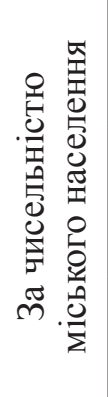 } & \multirow{2}{*}{$\begin{array}{l}\stackrel{P}{\dot{H}} \\
>\end{array}$} & LWO & \multirow[b]{2}{*}{$\begin{array}{l}y \\
t^{\prime}\end{array}$} & & & & & $\frac{a}{a}$ & $\frac{n}{\infty}$ & $\begin{array}{l}n \\
\Xi \\
=\end{array}$ & $\underline{\sigma}$ & & \\
\hline & & & вLכ!̣ & & & $\begin{array}{l}\hat{0} \\
n\end{array}$ & $\begin{array}{l}0 \\
i n \\
\text { in }\end{array}$ & â & $\begin{array}{l}\infty \\
\sigma^{*}\end{array}$ & & & & & \\
\hline & & & о.Ј9गЯ & $\begin{array}{l}n \\
\infty \\
\infty\end{array}$ & & $\begin{array}{l}\hat{\sigma} \\
n\end{array}$ & $\begin{array}{l}0 \\
i n\end{array}$ & $\hat{\infty}$ & $\hat{\sigma}$ & $\begin{array}{l}n \\
\infty \\
\infty\end{array}$ & $\begin{array}{l}2 \\
\stackrel{2}{=}\end{array}$ & $\hat{\sigma}^{\circ}$ & & \\
\hline & 宏 & & LWO & $\begin{array}{l}\infty \\
0^{\circ} \\
0\end{array}$ & & & & & $\frac{n}{\infty}$ & $\begin{array}{c}\infty \\
i \\
a \\
\text { and }\end{array}$ & 8 & $\stackrel{\imath}{\beth}$ & & \\
\hline & 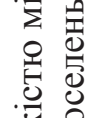 & $\stackrel{H}{\lambda}$ & вцЈ!̣ & $\begin{array}{l}\infty \\
\infty \\
\infty \\
0\end{array}$ & & ஓ્ત & $\hat{\theta}_{0}^{\circ}$ & $\stackrel{n}{\cong}$ & $\stackrel{8}{ }$ & & & & & 8 \\
\hline & ल. & & О.ОчगЯ & $\stackrel{\infty}{0}$ & & 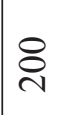 & $\hat{6}$ & 8 & $\begin{array}{l}+ \\
\dot{\sigma}\end{array}$ & 8 & 8 & $\stackrel{\sim}{\simeq}$ & & 8 \\
\hline$\frac{10}{7}$ & & ப். & LWO & $\begin{array}{l}\infty \\
\infty \\
\stackrel{\infty}{=}\end{array}$ & & & & & $\begin{array}{l}2 \\
\varnothing \\
\infty\end{array}$ & $\begin{array}{l}0 \\
\infty \\
\infty\end{array}$ & $\overrightarrow{0}$ & $\infty$ & $\begin{array}{l}0 \\
0\end{array}$ & \\
\hline $\begin{array}{l}0 \\
\dot{0} \\
\stackrel{\Xi}{*} \\
\dot{\sigma}\end{array}$ & $\begin{array}{l}\dot{0} \\
\stackrel{0}{0} \\
\stackrel{n}{0}\end{array}$ & $\lambda$ & BLJ!̣ & 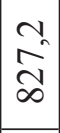 & & $\begin{array}{l}0 \\
\infty \\
\infty \\
\infty \\
\infty\end{array}$ & $\stackrel{0}{\Xi}$ & $\frac{a}{a}$ & $\begin{array}{c}n^{\prime} \\
\stackrel{\infty}{ \pm}\end{array}$ & $\stackrel{\sigma_{n}}{r}$ & & & & \\
\hline 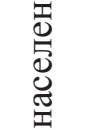 & & & ОıОчगЯ & 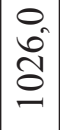 & & $\begin{array}{l}0 \\
\infty \\
\infty \\
0 \\
0\end{array}$ & $\stackrel{0}{\equiv}$ & $\vec{a}$ & $\begin{array}{l}0 \\
\dot{0} \\
\stackrel{2}{v}\end{array}$ & $\stackrel{\sigma_{n}}{\tilde{\sigma}}$ & $\overrightarrow{0}$ & $\infty$ & & \\
\hline 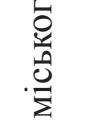 & & $\dot{\square}$ & LWO & 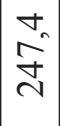 & & & & $\overrightarrow{0}$ & $\hat{\sigma}$ & $\begin{array}{l}n \\
\tilde{c} \\
2\end{array}$ & $\begin{array}{l}n \\
m \\
n\end{array}$ & $\underset{\infty}{\nabla_{\infty}}$ & $\begin{array}{l}0 \\
0\end{array}$ & \\
\hline 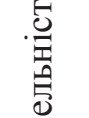 & $\begin{array}{l}\underset{0}{0} \\
\underset{0}{0} \\
2\end{array}$ & & вนつ!̣W & $\hat{2}$ & & $\begin{array}{l}\hat{\sigma} \\
\stackrel{2}{ }\end{array}$ & $\begin{array}{l}+ \\
\dot{8} \\
\infty\end{array}$ & \begin{tabular}{l}
0 \\
\multirow{2}{*}{} \\
$i$
\end{tabular} & $\begin{array}{l}\nabla_{0} \\
ٌ \\
\curvearrowleft\end{array}$ & & & & & \\
\hline$\vec{F}$ & $\stackrel{\infty}{\stackrel{\infty}{二}}$ & & оıочวЯ & $\stackrel{\vec{\Xi}}{\stackrel{\Xi}{\Xi}}$ & & $\begin{array}{l}\hat{\sigma} \\
\stackrel{\sigma}{\sigma}\end{array}$ & $\begin{array}{l}\nabla_{0} \\
\infty \\
\infty\end{array}$ & $\vec{\delta}$ & $\begin{array}{l}n \\
0^{2} \\
\stackrel{n}{N}\end{array}$ & $\begin{array}{l}n \\
0 \\
0\end{array}$ & $\begin{array}{l}n \\
m \\
m\end{array}$ & $\underset{\infty}{\nabla_{\infty}}$ & & \\
\hline & & ن & LWO & ㅇ & & & & & $\sim$ & $m$ & $\nabla$ & in & - & \\
\hline & $\stackrel{0}{6}$ & $\lambda$ & вцつ!̣W & $\stackrel{\circ}{N}$ & & $\sim$ & 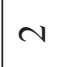 & $a$ & 으 & - & & & & $\sim$ \\
\hline 爻目 & & & О.О૧गЯ & in & & $\sim$ & 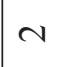 & $a$ & ㄱ & $\Xi$ & $\nabla$ & $n$ & - & $\sim$ \\
\hline . & & ن & LWO & $\vec{n}$ & & & & - & $\infty$ & $\Xi$ & $\nabla$ & $\nabla$ & & \\
\hline $\begin{array}{l}\frac{5}{0} \\
\frac{2}{n} \\
\theta\end{array}$ & 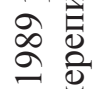 & $\lambda$ & Bцว!̣W & $\stackrel{\Xi}{\sim}$ & & - & $m$ & $\infty$ & $ㅇ$ & & & & & $\sim$ \\
\hline & & & ОıочวЯ & $n$ & & - & $m$ & $a$ & $\infty$ & $\Xi$ & $\nabla$ & $\nabla$ & & $\sim$ \\
\hline & & 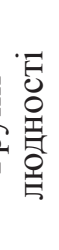 & & $\begin{array}{l}0 \\
0 \\
0 \\
0 \\
0\end{array}$ & 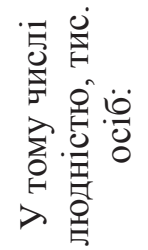 & 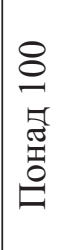 & $\begin{array}{l}8 \\
\text { - } \\
\text { ' } \\
\text { n }\end{array}$ & 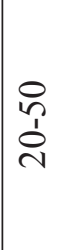 & 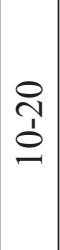 & $\frac{0}{1}$ & $\begin{array}{l}n \\
n\end{array}$ & $\stackrel{n}{-}$ & $\begin{array}{l}\bar{o} \\
\text { 慁 } \\
\sum_{\Sigma}^{2}\end{array}$ & 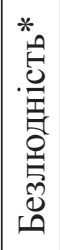 \\
\hline
\end{tabular}

过

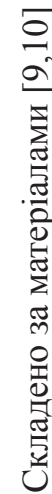


від їх людності, функцій, географічного положення тощо.

До другої групи ми віднесли міські поселення людністю більше 20 тис. осіб, кількість яких в Київщині протягом 1989-2016 рр. не змінилася i становила 13, або 23\% міської поселенської мережі. Що стосується демографічного потенціалу, то у цій групі кількість населення поступово збільшувалася, а іï питома вага за населення підвищилася з 63,7\% у 1989 р. до 65,4\% у 2016 р. Спостерігається тенденція подальшої концентрації міського населення у цій групі.

Третю групу становлять малі міські поселення людністю менше 5 тис. осіб, кількість яких протягом 1989- 2016p. збільшилася 38 до 10 (18\% мережі). В результаті цього демографічний потенціал цієї групи поселень збільшився на 21\%, але він залишався дуже малим і становив лише 2,6\% загальної кількості міського населення області. Ці поселення мають обмежену економічну базу для їх розвитку.

До четвертої належить унікальна група міських поселень, що втратили людність внаслідок Чорнобильської катастрофи. Це міста Прип'ять та Чорнобиль, з яких у 1986 р. були виселені всі мешканці через високе радіаційне забруднення місцевості в результаті Чорнобильської катастрофи. Незважаючи на безлюдність ці поселення не зняті 3 державного обліку і утворюють специфічну групу «поселень без населення».

Для більш глибокого суспільно-географічного дослідження міського розселення у Київщині необхідно окремо проаналізувати міста та селища міського типу.

Міста розглядаються нами як головна форма міського розселення. Як видно 3 табл. 1, у містах в кінці XX ст. було зосереджено три чверті міського населення Київщини. Більш того, спостерігалася тенденція збільшення населення міст і зменшення міських селищ. Протягом 1989-2016 рр. чисельність населення міст області збільшилася на 4,2\%, що зумовлене створенням у них нових робочих місць, зокрема у містах, розташованих у Київській приміській зоні. В результаті питома вага міст у чисельності міського населення Київщини підвищилася $з$ 76,2\% у 1989 р. до 80,6\% у 2016 р. Ці позитивні тенденції збережуться і у перспективі.

Географія міст Київщини має такі особливості:

- наявність двох безлюдних міст;

- місто Славутич підпорядковане Київській обласній раді, але розташоване на території Чернігівщини;

- густа мережа середніх та малих міст розташована у Київській приміській зоні.

Головними ознаками класифікації міст $є$ їх людність та функції. Як видно 3 табл. 1, зараз на Київщині $є$ два великих міста Біла Церква (207,7 тис. осіб) та Бровари (100,8 тис. осіб). Причому останнє зростало досить високими темпами і нещодавно увійшло до цієї групи. Середніх міст в області мало, лише два (Бориспіль та Ірпінь), темпи розвитку яких були низькими. Ще у
2008 р. в регіоні було три середніх міста, але Фастів зменшив людність і перейшов до групи малих міст. Найбільш поширеною в області є група малих міст (людністю менше 50 тис. осіб), яких у 2016 р. було 20 (77\% мережі міст), в них проживало 57\% міського населення регіону. До нових малих міст відносяться Ржищів та Буча, переведені до категорії міста у 1995 та 2006 р. відповідно. Малі міста структурно неоднорідні, серед них виділяються дві підгрупи:

- Міста людністю 21-50 тис. осіб збільшили людність у 1990-2010 рр. на 40\% у зв’язку з переходом до неї трьох міст (Фастів, Буча та Ржищів);

- Міста людністю менше 20 тисяч знаходяться у стадії деградації, тому що економіка не розвивається, переживають кризовий стан а населення мігрує. У цих 10 найменших містах людність зменшилась на 12,5\%. Цим містам потрібно 3 боку держави приділяти особливу увагу та надати фінансову допомогу.

Таким чином, у Київській області гостро стоїть проблема активізації соціально-економічного розвитку малих міст. Ця проблема на початку XXI ст. почала повільно вирішуватися в процесі реалізації двох загальнодержавних програм по малих містах, але через припинення їх державного фінансування ці програми так і не були виконані.

Міста області виконують різноманітні функції (промислові, транспортні, рекреаційні тощо), за якими виділено поліфункціональні (великі та середні міста) та монофункціональні (малі міста). До поліфункціональних належать такі типи міст: розвинені багатогалузеві, промислові центри 3 адміністративними функціями - 6; промислово транспортні адміністративні центри - 2; центри харчової промисловості 3 адміністративними функціями - 7; промислово транспортні центри 2. Монофункціональні міста об'єднують такі типи: енергетичні центри - 3; центри харчової промисловості - 3; центри промисловості по виробництву будівельних матеріалів - 2; рекреаційний центр - 1. Як бачимо, найбільш поширеними є типи міст 3 переважним розвитком харчової промисловості.

Селища міського типу $\epsilon$ важливою формою міського розселення, яка досить поширена у Київській області. У 2016 р. у 30 селищах міського типу проживало 199 тис. осіб, що на 28\% менше, ніж у 1989 р. Зменшення демографічного потенціалу міських селищ зумовлено багатьма причинами (демографічними, соціальними, економічними тощо). В результаті цього питома вага міських селищ у чисельності міського населення області знизилася з 23,8\% у 1989 р. до 19,4\% у 2016 р. В структурі селищної мережі переважають середні та великі селища (людністю 5 - 20 тис. осіб), на які у 2016 р. припадало 67\% всіх селищ, в них проживало $80,5 \%$ всього населення міських селищ. Більшість iз цієї групи селищ є райцентрами, що виконують адміністративні та соціальні функції.

На Київщині представлені такі типи селищ: центри харчової промисловості - 10; центри промисловості будівельних матеріалів - 4; центри машинобудування - 2; науково-освітні 
центри - 3; рекреаційні центри - 2. Як бачимо, найбільш поширеним $є$ тип селищ «центри харчової промисловості».

Враховуючи тенденцію розвитку міського розселення у 2001-2016 рр., особливості структури міст і селищ міського типу, нами розроблено прогноз розвитку міського розселення у Київській області та обгрунтовані напрями вирішення їх проблем. При цьому окремо розглядалися проблеми розвитку міст як головної форми міського розселення та селищ міського типу (Таблиця 2).

Великим містом Київщини є Біла Церква. Незважаючи на зростання іiї людності (на 7\% протягом 1990-2016 рр.), місто має певні проблеми розвитку, пов'язані із скороченням промислового виробництва, зростанням безробіття, зменшенням робочих місць. Для вирішення цих проблем потрібно збільшити інвестиції в економіку міста, модернізувати діючі промислові підприємства.

Проблеми розвитку середніх міст стосуються Борисполя та Броварів, які за останні 25 років збільшили людність на $21 \%$ і швидко розвивали промисловість, будівництво, транспорт і соціальну сферу. Це найбільш успішні міста Київщини, розвитку яких сприяло близьке розташування до м. Києва. Не зважаючи на це, подальший розвиток їх потребує вирішення деяких економічних, соціальних, екологічних проблем. Потрібно активізувати процес модернізації та технологічного оновлення діючих промислових підприємств, підвищити інвестиційну привабливість цих міст, особливо для іноземних інвесторів, розширити ринкову інфраструктуру, господарського комплексу цих міст.

Актуальною для Київщини є проблема розвитку малих міст, мережа яких розширилася. За напрямами демографічного розвитку за період 1990-2016 рр. малі міста потрібно поділити на 2 групи. До першої належать 7 міст, людність яких збільшилася на 23\%. Це міста, що мають вигідне географічне положення, більшість 3 них розташовані в ближній приміській зоні Києва, певну економічну базу i достатню кількість робочих місць. До другої групи належать 13 малих міст, що майже вдвічі більше першої, людність яких у вищезазначений період зменшилася на $12 \%$. Отже проблема розвитку стосується лише другої групи міст, які самостійно не можуть розвивати економіку та соціальну сферу і потребують державної підтримки. Що являють собою ці міста? Окрім Боярки та Узина 11 міст є центрами відповідних районів виконують декілька функцій (економічні, соціальні, адміністративно-управлінські тощо). Проте слабкий промисловий розвиток, дефіцит робочих місць, безробіття зумовлюють працездатне населення, особливо молодь виїздити у пошуках роботи та на навчання. При розробці шляхів вирішення проблем соціально-економічного розвитку малих міст

Таблиия 2

Прогноз міського розселення у Київському регіоні

\begin{tabular}{|c|c|c|c|c|c|c|c|c|}
\hline \multirow{3}{*}{ Групи людності поселень } & \multicolumn{4}{|c|}{2013} & \multicolumn{4}{|c|}{2020} \\
\hline & \multirow{2}{*}{$\begin{array}{c}\text { Число } \\
\text { Одиниць }\end{array}$} & \multirow{2}{*}{$\begin{array}{c}\text { Mict } \\
\% \\
\end{array}$} & \multicolumn{2}{|c|}{ Населення } & \multirow{2}{*}{$\begin{array}{c}\text { Число } \\
\text { одиниць }\end{array}$} & \multirow{2}{*}{$\begin{array}{l}\text { Mict } \\
\%\end{array}$} & \multicolumn{2}{|c|}{ Населення } \\
\hline & & & $\begin{array}{l}\text { тис. } \\
\text { осіб }\end{array}$ & $\%$ & & & $\begin{array}{l}\text { тис. } \\
\text { осіб }\end{array}$ & $\%$ \\
\hline \multicolumn{9}{|c|}{ Міста } \\
\hline Всього & 26 & 100 & 871 & 100 & 26 & 100 & 883 & 100 \\
\hline \multicolumn{9}{|l|}{ У т.ч. людністю тис. осіб: } \\
\hline $101-500$ & 1 & 3,8 & 211 & 24,2 & 2 & 7,7 & 322 & 36,6 \\
\hline $51-100$ & 2 & 7,7 & 159 & 18,2 & 1 & 3,8 & 63 & 7,1 \\
\hline $21-50$ & 11 & 42,3 & 366 & 42,0 & 11 & 42,3 & 367 & 41,5 \\
\hline $5-20$ & 10 & 38,5 & 135 & 15,6 & 10 & 38,5 & 131 & 14,8 \\
\hline Безлюдні & 2 & 7,7 & - & - & 2 & 7,7 & - & - \\
\hline \multicolumn{9}{|c|}{ Селища міського типу } \\
\hline Всього & 30 & 100 & 199 & 100 & 30 & 100 & 215 & 100 \\
\hline \multicolumn{9}{|l|}{ У т.ч. людністю тис. осіб: } \\
\hline Понад 10 & 7 & 23,3 & 87 & 43,7 & 5 & 16,7 & 69 & 32,2 \\
\hline $5-10$ & 13 & 43,3 & 86 & 43,2 & 10 & 33,3 & 80 & 37,1 \\
\hline 3-5 & 4 & 13,3 & 16 & 8,0 & 10 & 33,3 & 58 & 26,9 \\
\hline $1-3$ & 6 & 200 & 10 & 5,1 & 5 & 16,7 & 8 & 3,8 \\
\hline
\end{tabular}

Джерело: Розраховано за даними [8; 9] 
Київщини необхідний диференційований підхід, який має враховувати функції міст та їх місце у загальнодержавному територіальному поділі праці.

Дещо кращі умови розвитку матимуть поліфункціональні міста-районні центри, в яких поєднуються економічні, соціальні, адміністративні та управлінські функції. Цей тип включає два підтипи, що вирізняються повноваженнями органів місцевого самоврядування. До першого підтипу належить 5 міст обласного значення (Васильків, Переяслав-Хмельницький, Обухів, Фастів, Ірпінь), які мають сприятливі умови для розширення i модернізації промислового потенціалу. У цих містах розвинене машинобудування, що поєднується 3 хімічною, деревообробною, легкою та харчовою промисловістю. До другого підтипу слід віднести Богуслав та Миронівку, в яких розвинені машинобудування, легка й харчова промисловість. Розвиток цих міст повинен спрямовуватися на модернізацію та технічне оновлення діючих промислових підприємств.

$$
\text { Окремої уваги потребують }
$$

монофункціональних малих міст Київщини, що поділяються на два типи, які мають значні відмінності розвитку та вирішення існуючих проблем. До першого належить 6 міст-районних центрів 3 низьким рівнем промислового розвитку i спеціалізацією на одному виді промислової продукції. У 5 містах існують лише підприємства харчової промисловості 3 переробки сільськогосподарської продукції (Кагарлик, Сквира, Тараща, Тетіїв та Яготин), а у Вишгороді - електроенергетика. Вирішення проблем економічного розвитку малих міст - центрів харчової промисловості безпосередньо пов'язане iз модернізацією підприємств, підвищенням їх конкурентоспроможності та якості харчових продуктів, розширенням асортименту продукції, енергозбереженням, охороною природного середовища від забруднення, використанням вторинної сировини.

Другийтип монофункціональних містоб'єднує 8 міст, які не є райцентрами, а є промисловими центрами із низьким рівнем промислового розвитку. До першого підтипу належить 4 міста обласного значення, що мають деякі фінансові та управлінські переваги соціально-економічного розвитку і можуть розвиватися самостійно без державного втручання (Березань, Буча, Ржищів та Славутич). Другий підтип складають 4 міста районного значення, що мають обмежені можливості для свого розвитку i потребують державної підтримки (Боярка, Вишневе, Узин та Українка).

За спеціалізацією промисловості ці міста можна поділити на такі групи:

а) енергетичні центри - Українка, Славутич;

б) машинобудівні центри - Ржищів, Вишневе;

в) центри по виробництву будівельних матеріалів - Березань, Буча;

г) центри харчової промисловості

Узин, Боярка.
Основними напрямами розвитку другого типу малих міст має бути підвищення технічного рівня i модернізація діючих підприємств, підвищення їх ефективності i конкурентоспроможності, будівництво нових промислових підприємств, технічно взаємопов'язаних із діючими, підвищення інвестиційної привабливості цих міст, зміцнення транспортної та соціальної інфраструктури.

Як бачимо, вирішення проблеми розвитку малих міст Київщини є процесом складним, тривалим i комплексним, який потребує координації зусиль держави та органів місцевого самоврядування. Вирішення актуальних проблем міського розселення у Київському регіоні сприятиме позитивним зрушенням у структурі міського розселення, про що свідчать дані наведеної таблиці.

За нашим прогнозом, у перспективі до 2020 року міська поселенська мережа Київщини не зазнає суттєвих змін, але можливі деякі трансформації. Очікується, що чисельність населення міст збільшиться на 14\%. У зв'язку зі значним соціальноекономічним розвитком міста Бровари, воно перейде iз середніх до групи великих міст і частка цієї групи удвічі підвищиться, а частка середніх міст знизиться (у ній залишиться лише Бориспіль). Щодо малих міст, то кількість їх (21) та питома вага у мережі не зміниться (81\%), а у чисельності мешканців міст Київщини трохи знизиться (3 57,6\% до 56\% у 2020 р.), що буде зумовлене низькими темпами соціальноекономічного розвитку малих міст, а деякі 3 них i надалі перебуватимуть у стані деградації. У разі державної підтримки найбільші шанси у наступні 6-7 років перейти до групи середніх міст мають Ірпінь, Вишневе та Обухів, розташовані поблизу Києва.

Важливу роль у розселенні міського населення Київщини відіграють селища міського типу, мережа яких у перспективі до 2020 року не зміниться. Розташовані поблизу Києва селища Коцюбинське та Гостомель, які швидко розвиваються і досягли критеріїв міста, доцільно перевести до категорії міст, що сприятиме зменшенню міграції у столицю. Як видно з таблиці 2, в перспективі до 2020 року зрушення в структурі селищ будуть пов'язані зі збільшенням удвічі кількості середніх селищ (людністю 3-5тис. осіб). Якщо у 2013 р. 43\% всіх селищ припадало на великі селища (людністю 5-10 тис. осіб), то у 2020 р. частка їх зменшиться до 33\%, а середніх - збільшиться (3 13 до 33\%). Проте за чисельністю населення питома вага великих селищ хоча й зменшиться(3 43\% у 2013 р. до $37 \%$ у 2020 р.), але в них буде зосереджена найбільша кількість населення порівняно 3 іншими групами людності селищ. Отже, спостерігатиметься тенденція зміцнення середньої ланки селищного розселення міського населення Київського регіону, що сприятиме стабілізації селищної мережі та розвитку селищ різних функціональних типів та груп людності.

Висновки. Проведений аналіз динаміки та структури міського розселення у Київській області показав існування регіональних закономірностей i тенденцій розвитку його в незалежній Україні. Близьке розташування до Києва як до столиці 
держави мало величезний вплив та територіальну структуру міського розселення та формування регіональної системи розселення. У територіальній структурі міського розселення у регіоні чітко виділяються Київська приміська та периферійна зони міського розселення, які збережуться у перспективі до 2020 року. Очікується відносна стабільність міської поселенської мережі у прогнозованій перспективі.

\section{References:}

1. Bulycheva T. Osoblivostì formuvannâ i rozvitok Kïvs'koï regional'noï sistemi rozselennâ [Kyiv regional settlement system: specificity of shaping and development]. Abstract from PhD Thesis. Kyiv: Taras Shevchenko National University of Kyiv, 1998, 19 p. (In Ukrainian).

2. Volovyk L. Periferìni rajoni Stoličnoï oblastì: gospodars’kij kompleks, social'ni problemi ta naprâmi ïh virišennâ (na prikladi Kï̈vs'koï oblasti) [Kyiv Region periphery: economy, social issues and ways to solve them]. Abstract from PhD Thesis. Kyiv: Institute of Geography, National Academy of Sciences of Ukraine, 2012,20 p. (In Ukrainian).

3. Dotsenko A. Teritorìal'na organìzacîa rozselennâ na Kï̈vŝinì ta šlâhi ïï udoskonalennâ [Territorial organization of settlement in Kyiv Region and ways to improve it]. Kyiv Geographical Bulletin, 2002, Vol. 1., pp. $130-113$. (In Ukrainian).

4. Dotsenko A., Zinych V., Velykokhatko O. Regìnal'ne rozselennâv Ukraïnì: stan ì prognoz [Regional settlement in Ukraine: current state and forecast], Kyiv: Fenix, 2007, 376 p. (In Ukrainian).

5. Dotsenko A. Problemi teritorìl'noï organìzaciï rozselennâ v Kïvs'komu regìonì [Issues of spatial settlement of population in the Kyiv Region]. Ekonomika i upravlinnâ: problemi nauki ta praktiki. Zbirnik materialiv konferencii [Economics and Management: Issues of Science and Practice. Conference Procedings], Dnipropetrovsk: Gerda, 2012, pp. 173-175. (In Ukrainian).

6. Ischuk S., Gladkey O. Kï̈s'ka gospodars'ka aglomeracîâ: dosvìd regìnal'nogo menedžmentu [Kyiv economic agglomeration: experience of regional management], Kyiv: Oberih, 2005, 239 p. (In Ukrainian).

7. Solohub Yu. Mis’ke rozselennâ Stoličnogo regìonu: suspil’no-geografǐčne doslidžennâ [Urban settlement in Capital Region from the viewpoint of human geography]. Abstract from PhD Thesis. Kyiv: Taras Shevchenko National University of Kyiv, 2009, 23 p. (In Ukrainian).

8. Statistical Bulletin of Kyiv Region for 2013, Kyiv: State Statistics Service of Ukraine, 2014,478 p. (In Ukrainian).

9. Statistical Bulletin of Kyiv Region for 2016, Kyiv: State Statistics Service of Ukraine, 2017,478 p. (In Ukrainian).

10. Quantity of Ukrainian population on January 1, 2017, Kyiv: State Statistics Service of Ukraine, 2017,112 p. (In Ukrainian).

\section{Список використаних джерел:}

1. Буличева Т. В. Особливості формування і розвиток Київської регіональної системи розселення / Т. В. Буличева. Автореф. дис. к. г. н. - К.: КНУ, 1998. - 19 с.

2. Воловик Л. М. Периферійні райони Столичної області: господарський комплекс, соціальні проблеми та напрями їх вирішення (на прикладі Київської області) / Л. М. Воловик. Автореф. дис. к. г. н. К.: ІГ НАНУ, 2012. $-20 \mathrm{c}$.

3. Доценко А. І. Територіальна організація розселення на Київщині та шляхи їі удосконалення / А. I. Доценко // Київський географічний щорічник. - 2002. - Вип. 1. - С. 130-113.

4. Доценко А. І. Регіональне розселення в Україні: стан і прогноз / А. І. Доценко, В. Т. Зінич, О. Т. Великохатько. - К.: Фенікс, 2007. - 376 с.

5. Доценко A.I. Проблеми територіальної організації розселення в Київському регіоні / А. І. Доценко // Економіка і управління: проблеми науки та практики. Зб. матер. конф. - Дніпропетровськ: Герда, 2012. - C. 173-175.

6. Іщук С.І. Київська господарська агломерація: досвід регіонального менеджменту / С. I. Іщук, О. В. Гладкий. - К.: ВГЛ «Оберіг», 2005. - 239 с.

7. Сологуб Ю. І. Міське розселення Столичного регіону: суспільно-географічне дослідження

/ І. Ю. Сологуб. Автореф. дис. к. г. н. - К.: КНУ, 2009. - 23 с.

8. Статистичний щорічник Київської області за 2013 рік. - К.: Держстат України, 2014. - 478 с.

9. Статистичний щорічник Київської області за 2016 рік. К.: Держстат України, 2017. - 478 с.

10. Чисельність наявного населення України на 1 січня 2017 року. - К.: Держстат України, 2017. - 112 с. 